Kinin virker ved muskelkramper

Muskelkramper kan ha mange årsaker, og kinin brukes ved alle former, men det har vært usikkerhet om effektivitet og sikkerhet. Ifølge en ny Cochrane-oversikt er det moderat kunnskapsgrunnlag for at kinin signifikant nedsetter frekvens og intensitet av muskelkramper ved en dosering på 200-500 mg/dag (Cochrane Database Syst Rev 2010; nr. 12: CD005044). Men patofysiologien ved muskelkramper og kinins virkningsmekanisme er sparsomt belyst.

Studien omfattet 23 randomiserte, kontrollerte studier av 1586 personer $\mathrm{i}$ alle aldre med muskelkramper. Sammenliknet med placebo reduserte kinin signifikant antallet kramper over to uker med $28 \%$, krampeintensiteten med $10 \%$ og antallet krampedager med $20 \%$.

\section{Skjev publisering}

Negative eller inkonklusive resultater er vanskeligere å få publisert enn positive funn, også i kirurgien (Ann Surg 2011; 253: 619-23). Forskerne undersøkte 2457 artikler fra 15 vitenskapelige tidsskrifter innen kirurgi. Disse ble kategorisert i tre grupper etter impaktfaktor.

Tidsskrifter med høy impaktfaktor publiserte signifikant færre negative og inkonklusive studier $(5-7 \%)$ i forhold til tidsskrifter med middels og lav impaktfaktor. Andelen av randomiserte, kontrollerte studier varierte fra $18-21 \%$ i de fem høyest rangerte tidsskriftene sammenliknet med $6-14 \%$ i de fem lavest rangerte. Forfatterne mener at det bør være kvalitet, og ikke resultater, som bør være avgjørende for publisering.

\title{
LAR-pasienter får dårlig smertebehandling
}

\section{Pasienter under legemiddelassistert rehabilitering får ofte smertebehand- ling som har liten effekt og som kan redusere evnen til å mestre rus.}

Det er vanskelig å behandle smerter hos slike pasienter. Opioider med hurtig og kortvarig effekt bør unngås, og behandlingen må være så effektiv at pasientene ikke fristes til å kjøpe opioider illegalt. Vi brukte data fra Reseptregisteret for å unders $\emptyset$ ke hvilke analgetika som forskrives til pasienter under legemiddelassistert rehabilitering (LAR) (1).

Blant LAR-pasienter var andelen som mottok opioider i løpet av et år like høy som i den generelle befolkningen (10\%). Det hyppigst forskrevne legemidlet var paracetamol-kodein i kombinasjon, til tross for at paracetamol-kodein er for svakt til at man kan forvente effektiv smertelindring i denne pasientgruppen. Dessuten kan midlet utløse rus hvis det brukes galt eller i kombinasjon med benzodiazepiner. Om lag $30 \%$ av LAR-pasienter som ikke hadde brukt analgetika forrige år fikk forskrevet paracetamol-kodein eller et opioid alene første gang de fikk resept på analgetika.

I sykehus kan akutte smerter ofte lindres effektivt med epidural eller perifer blokade. Utenfor sykehus må man basere smertebehandlingen på tabletter, stikkpiller eller smerteplaster. Paracetamol og ikke-steroide antiinflammatoriske legemidler (NSAID) er førstevalget og bør alltid foretrekkes. Ved kontraindikasjoner eller utilstrekkelig lindring bør man $\varnothing \mathrm{ke}$ dosen av det opioidet pasienten bruker i sin LAR-behandling fremfor å supplere med et annet opioid (2).

\section{Olav Magnus S. Fredheim}

olav.m.fredheim@ntnu.no

Avdeling for smerte og sammensatte lidelser St. Olavs hospital

\section{Litteratur}

1. Fredheim OM, Borchgrevink PC, Nordstrand B et al. Prescription of analgesics to patients in opioid maintenance therapy: a pharmacoepidemiological study. Drug Alcohol Depend 2011, doi: 10.1016/ j.drugalcdep.2010.12.014.

2. Fredheim OM, Nøstdahl T, Nordstrand B et al. Behandling av akutte smerter under legemiddelassistert rehabilitering. Tidsskr Nor Legeforen 2010; 130: 738-40. 